\title{
Redactioneel
}

\section{Toezicht, de stad en de regio}

\author{
Martijn Groenleer*
}

\section{Inleiding}

Al geruime tijd verplaatsen beleid en bestuur zich, weg van het rijksniveau: enerzijds naar het internationale en vooral Europese niveau, anderzijds naar het lokale en regionale niveau. Nieuwe maatschappelijke opgaven, zoals klimaatverandering en de energietransitie of migratie en integratie, leiden tot verschuivingen in taken en bevoegdheden tussen overheden. Hetzelfde geldt voor nieuwe wet- en regelgeving zoals die in het sociale domein of op het terrein van de leefomgeving. Die verplaatsing van beleid en bestuur heeft meestal ook belangrijke gevolgen voor het toezicht.

Over de verschuiving van taken en bevoegdheden naar Europa, en wat daarvan de implicaties zijn voor het toezicht, is al veel geschreven, ook in dit tijdschrift. Zo weten we inmiddels dat er sprake is van aanzienlijke verschillen in toezichtpraktijken tussen Europese landen, maar ook dat inspecties en toezichthouders regelmatig samenwerken met hun Europese collega's om die verschillen te reduceren. ${ }^{1}$ We zien een proces van Europeanisering van het toezicht, waarbij de rol van de Europese Commissie is toegenomen, het aantal informele en formele netwerken op Europees niveau sterk is

Prof. dr. M.L.P. Groenleer is hoogleraar recht en bestuur aan Tilburg University en directeur van het Tilburg Center for Regional Law and Governance (TiREG) en redactielid van Tijdschrift voor Toezicht.

1. M.L.P. Groenleer, 'Samenwerking tussen inspecties over de grenzen heen: vormen, redenen, uitdaging en strategie', TVT 2016, afl. 3, p. 35-55.

2. E. Versluis en J. Polak, Het effect van internationale netwerken en agentschappen in nationale implementatie van Europees beleid, TVT 2017, afl. 2, p. 28-34 gegroeid $^{2}$ en er zelfs onafhankelijke Europese inspecties en toezichthouders zijn opgericht. ${ }^{3}$

De Europeanisering van het toezicht betekent overigens niet dat nationale inspecties en toezichthouders er niet meer of minder toe doen. Dat blijkt ook uit het interview (opgenomen in dit nummer) dat $T v T$-redactieleden Rein Halbersma en Karin van Wingerde hadden met Hanzo van Beusekom, lid van de raad van bestuur van de Autoriteit Financiële Markten, als onderdeel van de $T v T$-interviewestafette. Integendeel. Het betekent wel dat inspecties en toezichthouders strategischer te werk moeten gaan in de complexe en dynamische werkelijkheid van het meerlagig toezichtsysteem.

Veel minder is geschreven over processen van decentralisatie en regiovorming en wat die betekenen voor het toezicht. Sinds 2015 zijn gemeenten bijvoorbeeld verantwoordelijk voor de uitvoering van de Wet maatschappelijke ondersteuning (Wmo), alsook het toezicht daarop.

Hoe hebben gemeenten het toezicht georganiseerd? Wat kunnen we zeggen over hoe het toezicht in de praktijk werkt? We weten dat op rijksniveau onder de noemer 'Toezicht Sociaal Domein' (TSD) wordt samengewerkt door de Inspectie Gezondheidszorg en Jeugd, de Inspectie van het Onderwijs, de Inspectie Justitie \& Veiligheid, en de Inspectie Sociale Zaken en Werkgelegenheid, en dat de gemeentelijke Wmo-toezichthouder daarbij betrokken is. Maar wat behelst die betrokkenheid precies? En hoe verhoudt Rijkstoezicht zich tot gemeentelijke taken en verantwoordelijkheden? We hebben nauwelijks nog een antwoord op deze en andere vragen. Deels heeft dit te maken met het recente karakter van de verplaatsing van bestuur en beleid naar gemeente en regio. Er was simpelweg eerder niet veel om over te schrijven. Deels kan dit worden verklaard

3. A.T. Ottow en S.A.C.M. Lavrijssen, 'Het Europese recht als hoeder van de onafhankelijkheid van nationale toezichthouders', TVT 2011, afl. 3, p. 34-50. 
door het Haagse perspectief dat veel van de analyses hebben en de aandacht die daarin vooral uitgaat naar de rol van de rijksoverheid (ministers, departementen, rijksinspecties en -toezichthouders). Wat er kan worden geschreven over de lokale en regionale dimensie van toezicht wordt daardoor vaak niet geschreven, ook niet in dit tijdschrift. ${ }^{4}$

Dit terwijl ontwikkelingen op lokaal en regionaal niveau belangrijke en steeds urgentere vragen opwerpen, juist ook voor het toezicht. Hoe wordt in het licht van decentralisatie en regiovorming al dan niet verplicht gestalte gegeven aan toezicht op decentraal niveau? Welke rol spelen steden en regio's als toezichthouders? Op welke wijze worden rollen en verantwoordelijkheden verdeeld tussen toezichthouders op verschillende niveaus? Welke rol is er voor Rijkstoezichthouders? Wat vraagt de gedeeltelijke verplaatsing van hen, in relatie tot gemeenten, regio's en provincies? En wat betekent dit alles zowel in termen van structuren als in termen van strategieën voor toezicht in een lokale en regionale setting?

In dit themanummer gaan we in op deze en andere vragen omtrent toezicht in een lokale en regionale setting. We spreken bewust niet van 'lokaal toezicht' of 'regionaal toezicht', net zoals het problematisch is te spreken over 'Europees toezicht'. Dit toezicht manifesteert zich bij uitstek in een meerlagig systeem waarin een veelheid aan toezichthouders actief is, en het vooral gaat om hun onderlinge interactie op (horizontaal) en tussen (verticaal) de verschillende niveaus. Bovendien zou het daardoor lijken alsof er bij decentralisatie en regiovorming altijd sprake is van volledige overheveling van taken en verantwoordelijkheden, terwijl die overheveling vaak gedeeltelijk is en taken en verantwoordelijkheden gedeeld worden. Het themanummer vormt slechts een eerste en voorlopige poging het geconstateerde gat in de literatuur te dichten. Meer aandacht en onderzoek zijn nodig.

Het themanummer bevat bijdragen van zowel theoretische als meer empirische aard, en met zowel een bestuurskundig als meer juridisch karakter. De bijdragen richten zich onder meer op het toezicht op samenwerking tussen gemeenten in de regio, het toezicht op integriteit van lokale bestuurders, informatiegestuurd handhaven in Amsterdam, en de onderlinge verhoudingen tussen Gedeputeerde Staten en omgevingsdiensten bij het toezicht op risicovolle ondernemingen. Hieronder introduceren we het themanummer en plaatsen we de bijdragen in een breder perspectief.

4. Maar zie: J.J.H. Verkroost en A.M. Zeeman, 'Samenwerking Rijkgemeente bij het toezicht op de Leerplichtwet', TVT 2016, afl. 4, p. 58-65.

\section{Interbestuurlijk toezicht en de rol van gemeenteraden en Rijksinspecties}

Bij de lokale of regionale dimensie van toezicht wordt vaak als eerste en enige gedacht aan interbestuurlijk toezicht. Dat is het toezicht dat plaatsvindt in het kader van de verhoudingen tussen verschillende overheidslagen, dus tussen Rijk, provincies, gemeenten, regio's en waterschappen. Het gaat daarbij in essentie om toezicht van hogere overheden op de taakbehartiging door lagere overheden. Het interbestuurlijk toezicht is enkele jaren geleden ingrijpend gewijzigd. Op 1 oktober 2012 werd de wet Revitalisering Generiek Toezicht (RGT) van kracht, die het toezicht op provincies en gemeenten poogt te vereenvoudigen. In principe is het nu zo dat het Rijk toezicht houdt op de provincies, en de provincies op de gemeenten. Op het gebied van bijvoorbeeld leefomgevingsvraagstukken is het dus niet langer de Rijksinspectie maar de provincie die toezicht houdt op de gemeenten.

Belangrijk uitgangspunt van de wet RGT is enerzijds het vertrouwen dat een bestuurslaag zijn taken goed uitvoert, en anderzijds de veronderstelling dat het horizontaal toezicht, dus het toezicht tussen gemeentebestuur en gemeenteraad en tussen provinciebestuur en Provinciale Staten, goed geregeld is en naar behoren functioneert. Uit de evaluatie van de wet RGT (2017) blijkt echter dat de raad die veronderstelde controle op de gemeentelijke uitvoering van taken niet of nauwelijks uitvoert. In haar bijdrage aan dit themanummer laat Klaartje Peters, mede gebaseerd op lokaal rekenkameronderzoek, zien dat gemeenteraden worstelen met hun controlerende taak, zeker ten aanzien van grote regionale samenwerkingsverbanden zoals de Veiligheidsregio, de GGD en de Omgevingsdienst. De kwaliteit van de informatievoorziening over prestaties van die verbanden is een belangrijk knelpunt. In dit verband wordt ook wel gesproken over het 'zwarte gat' van regionale samenwerking, waarin taken en bevoegdheden verdwijnen, zonder dat daar verantwoording, controle en toezicht, en om te beginnen informatie, tegenover staan.

Uit het onderzoek van Peters blijkt, interessant genoeg, dat Rijksinspecties en provincies in hun rol als interbestuurlijk toezichthouder regelmatig onderzoek doen naar gemeenten en hun samenwerkingsverbanden. Onderzoek dat voor gemeenteraden uiterst bruikbaar is, maar waar ze maar weinig gebruik van lijken te maken, mede doordat zij volgens Peters niet worden geïformeerd over de onderzoeken en de resultaten ervan. Peters pleit voor een verandering, die wordt ondersteund door Marcel van Dam, in zijn korte reactie op het artikel van Peters: er moet bij toezichthouders meer oog komen voor het belang van gemeenteraden als eerste controleur van het gemeentebestuur, niet in de laatste plaats waar het taken betreft die regionaal zijn georganiseerd. Volgens Van Dam zou het ministerie van BZK hierbij een centrale rol moeten spelen, als systeemver- 
antwoordelijke. Saillant detail is dat bij de herziening van het interbestuurlijk toezicht nu juist het uitgangspunt was dat dit toezicht aanvullend (in plaats van voorwaardelijk) moest zijn op de democratische controle, ofwel het horizontale toezicht, door de gemeenteraden.

Wellicht dat de vernieuwing van het interbestuurlijk toezicht, zoals afgesproken in het Interbestuurlijk Programma, soelaas kan bieden. Volgens het IBP en de Agenda toekomst van het (interbestuurlijk) toezicht die uit het IBP voortvloeit, zou interbestuurlijk toezicht aan moeten sluiten bij de gezamenlijke bestuurlijke aanpak van maatschappelijke opgaven. Een nieuwe wijze van toezicht waarin regels nog steeds belangrijk zijn, maar er ook ruimte is voor maatwerk bij de uitvoering. En waarin interactie, dialoog en samenwerking tussen de verschillende bestuurslagen die bij toezicht betrokken zijn essentieel is. Peters merkt terecht op dat in de Agenda voorbij wordt gegaan aan de rollen en de verantwoordelijkheden van de verschillende bestuursorganen, waardoor onderbelicht blijft wat de rol van volksvertegenwoordigers op lokaal niveau zou kunnen zijn, in het bijzonder bij het uitoefenen van toezicht op regionale samenwerking.

\section{Tussen lokale autonomie en bovenlokale doorzettingsmacht}

Waar Peters het perspectief van de lokale volksvertegenwoordiging en haar verantwoordelijkheid als controlerend en toezichthoudend orgaan centraal stelt, richt Niels Karsten zich in zijn essay op een ander vraagstuk rondom toezicht in een lokale en regionale setting: de mogelijke aantasting van de gemeentelijke autonomie door het Rijk en dan in het bijzonder op het terrein van bestuurlijke integriteit. De integriteit van het lokaal bestuur en het versterken van de integriteitscultuur in gemeenten staan hoog op de landelijke politiek-bestuurlijke agenda. De minister stelt dat het huidige instrumentarium van het generieke toezicht tekortschiet en er behoefte is aan meer middelen en instrumenten. Daarom verkent ze nieuwe vormen van interbestuurlijk toezicht vanuit het Rijk en de provincie.

Karsten betoogt dat maatregelen vanuit het Rijk al snel op gespannen voet staan met de lokale autonomie, die een belangrijke pijler vormt van de gedecentraliseerde eenheidsstaat. Centraal ingrijpen zou in strijd zijn met het recht, en de bestuurlijke verhoudingen aanzienlijk veranderen. Volgens Karsten is het daarom passender om eerst binnen het lokaal bestuur op zoek te gaan naar innovatieve vormen van toezicht, naast het versterken van de positie van de burgemeester. Hij noemt als voorbeeld commissies vanuit de gemeenteraad of een lokale integriteitsfunctionaris. In sommige gevallen, waarin niet kan worden uitgegaan van het zelfreinigende vermogen van het lokaal bestuur, zullen evenwel bovenlokale oplossingen nodig zijn. In zulke gevallen kan worden gedacht aan een grotere rol voor de commissaris van de Koning. Een ander spoor dat Karsten in zijn bijdrage verkent, is het aanscherpen van de bestuurlijke randvoorwaarden. Het gaat hierbij om maatregelen gericht op het bevorderen van integer gedrag en handelen van politici en bestuurders.

In zijn conclusies stelt Karsten dat het ontbreken van mogelijkheden voor effectief centraal toezicht op lokale bestuurlijke integriteit vooraleerst moet worden opgelost door het gebruiken en eventueel creëren van mogelijkheden voor zulk toezicht op lokaal niveau. Vanuit de gedachte dat dit zowel effectiever als legitiemer zal zijn. Maar niet zonder 'de schaduw van toezicht' vanuit het Rijk of de provincie en zonder de voortdurende inspanningen om de lokale integriteitscultuur te versterken. Zijn conclusies zijn daarmee in lijn met die van Peters en de rol die zij om te beginnen ziet voor lokale volksvertegenwoordigers. De vraag is in hoeverre Karsten's conclusies ten aanzien van toezicht op bestuurlijke processen ook opgaan voor toezicht op beleidsinhoudelijke beslissingen, zoals op de terreinen die Peters in haar bijdrage onder de loep heeft genomen.

\section{Toezicht en handhaving in en door gemeenten en provincies}

Naast het toezicht vanuit Rijk en provincie op het bestuur en beleid van gemeenten en regio's, hebben lokale en regionale overheden zelf ook toezicht- en handhavingstaken. Denk op lokaal niveau aan het aanpakken van overlast in de openbare ruimte, de afhandeling van horecaklachten, het verwijderen van fietsen, het controleren van brandveiligheid, of de handhaving op de verhuur van eigen woningen. In hun bijdrage, gebaseerd op tien jaar lokaal rekenkameronderzoek, gaan Daniëlle van der Wiel en collega's in op de uitdagingen waar de handhaving in Amsterdam voor staat. Het werkgebied is enorm en de stad wordt steeds drukker en diverser. Tegelijkertijd blijven taken toenemen en is lokale capaciteit schaars. In Amsterdam en elders wordt de oplossing gezocht in 'informatiegestuurd handhaven'. Dat lijkt logisch, maar blijkt verre van eenvoudig. Een voorbeeld waarin dit niettemin lukt, is een stadsdeel in Amsterdam waar harde en zachte informatie worden samengebracht en waarin de informatiegestuurde werkwijze wordt gecombineerd met een gebiedsgerichte aanpak.

De laatste bijdrage aan dit themanummer komt van Edward Brans en Katrien Winterink. Zij richten zich op het toezicht op en de handhaving van het strenge veiligheidsregime voor de meest risicovolle bedrijven van Nederland dat is neergelegd in het Besluit risico's zware ongevallen (Brzo) uit 2015. Toezicht en handhaving worden uitgevoerd door zes gespecialiseerde omgevingsdiensten (zoals de DCMR Milieudienst Rijnmond), die regionaal zijn georganiseerd. Ze vallen onder de verantwoordelijkheid van het provinciebestuur, Gedeputeerde Staten, dat de omgevingsdiensten heeft gemandateerd. 
Brans en Winterink stellen vast dat er niet of nauwelijks (afdoende) afspraken worden gemaakt over de onderlinge aansprakelijkheid in geval van schade bij derden als gevolg van (gebrekkig) handelen van de omgevingsdiensten. Juridisch gezien is het volgens Brans en Winterink wel degelijk raadzaam om zulke afspraken te maken. Die scheppen vooraf namelijk duidelijkheid en kunnen achteraf onzekerheid, discussies en geschillen voorkomen, zoals daarvan in het verleden sprake is geweest.

\section{Naar een onderzoeksagenda}

Dit themanummer richt zich op een in de literatuur en ook in dit tijdschrift vooralsnog onderbelichte dimensie van toezicht en handhaving, de lokale en regionale. Een dimensie die steeds belangrijker lijkt te worden onder invloed van processen van decentralisatie en regiovorming. In dit themanummer worden slechts enkele vragen omtrent toezicht in een lokale en regionale setting beantwoord, en dan ook nog op een zeer voorlopige wijze. Het themanummer roept vooral veel vragen op die nadere aandacht en systematisch en diepgravend vervolgonderzoek vergen, vanuit verschillende theoretische perspectieven, en met gebruik van uiteenlopende methoden.

Het is opmerkelijk dat zulke vragen geen onderdeel vormen - of in ieder geval niet expliciet - van de Wetenschapsagenda Toezicht uit 2018. Daarin wordt vooral verwezen naar de gevolgen voor toezicht en handhaving van voortschrijdende globalisering en snelle technologische ontwikkelingen en de vragen die hieruit voortvloeien voor met name Rijkstoezichthouders en -inspecties. Wij pleiten hier daarom voor een aanvullende onderzoeksagenda. Een agenda die zich ook richt op bestudering van bestaande en in ontwikkeling zijnde structuren en strategieën voor toezicht in een lokale en regionale setting, parallel aan wat er internationaal en nationaal gebeurt, en voorbij interbestuurlijk toezicht. Een onderzoeksagenda voor toezicht, de stad en de regio. 